\title{
Evaluation of Education Policy at Baduy Society, Lebak District - Banten Province
}

\author{
Harits Hijrah Wicaksana \\ STISIP \\ Setia Budhi Rangkasbitung \\ Lebak, Indonesia \\ haritshijrah@gmail.com
}

\author{
Asep Sumaryana \\ Public Administration at FISIP \\ UNPAD \\ Bandung, Indonesia
}

\begin{abstract}
The main issue in this research is evaluation of education policyin Baduy Society, Lebak District - Banten Province. The research aimed at explaining empirical facts, understanding the process, and describing the problems and causal factors of unimplemented education policy in Lebak District.Qualitative approach was used by using purposive method. Data were collected by in-depth interview, observation, and documentary study. For data analysis,Stake's(1975) responsive evaluation model was used.The result shows that the evaluation of education policy in Lebak Districtis based on Regional Regulation, Number 2/2010 about Education Development in Lebak Districtand has not been implemented because it is not supported by the Regent Regulation as the operational guidance in the evaluation of education policy itself.Furthermore, the stakeholders in this policy has not taken integrated implementation of education policy as well, especially within Baduy society. The policy released by the regional government as the responsibility form to public needs should reflect equity and justice values. Therefore, the policy evaluation determined by integrity and concern to local wisdom still holds based on the local custom, so the policy will correspond to the ideal expectations.
\end{abstract}

Keywords - evaluation, education policy, local wisdom

\section{INTRODUCTION}

The average length of schooling in Lebak District is only 6.2 years in 2010, and decreased to 5.8 years in 2016. The government identifies the educational problems in the district in which any follow-up taken will never succeed $100 \%$ due tothe demography of Baduy tribe.So far, the focal reason is because the tribe forbids its residents to go to formal schools, but the people do not really forbid the residents to learn.The legal basis for the implementation of the education system in Lebak District is contained in Lebak District Regulation No. 2/2010 about education realization in Lebak District. Specifically, there has not been a more specific policy dicussing education within Baduy society that prohibits schooling from either the local regulations or the regent regulations.

The problem statement in this research is: there is a gap between the facts and the results of evaluation on education policy among Baduy society. It suggests that the formal school ban for their indigenous communities is actually not as sacred as we might think.Education is already and is running with a model or a special formula and certainly different from the general concept of Indonesian modern education. The suitable educational concepts needed by their communities do not conflict with their custom law, and the gap or opportunity according to the author does exists.In other words, a growing number of schools within this societyare Baduy alternative schools. These schools run without violating customs in whichthey only teach reading, writing, and numeracy skills.

From the statement of the problem, the formulation of the research question which is used as the foundation in this research is: "How is the evaluation of education policy in Baduy people of Lebak District?"

\section{LITERATURE REVIEW}

The main theory in this evaluation study is a responsive evaluation model developed by Robert Stake (1975) in Wirawan (2011:89-91). According to him,evaluation is considered responsive if it meets three criteria, namely: (1) Orienting to program activities than program objectives; (2) Responding to the informant requirement of the audience; and (3) Valuing different perspectives of the people served are reported in the success and failure of the program.Furthermore, educational evaluators should work for and gain the support of educators who provide the educational services. They serve different types of people including: teachers, school administrators, curriculum developers, taxpayers, legislators, financial sponsors, and the societies who often have different needs one another.

\section{RESEARCH METHOD}

The research method used is descriptive qualitative because it is relevant with the objective of this study; that is observing the evaluation of education policy within Baduy society. According to Creswell, (2010:4-5) qualitative method is for exploring and understanding the meaning from some individuals or groups of people derived from their social or humanitarian problems.

The informants are the Head of Education and Culture Office of Lebak District, the Secretary of Education Office of Lebak District, the Head of Early Childhood Education and Informal Education (PAUDNI) of Lebak District, the Vice of Jaro Tangtu Baduy In Cibeo, the Regent of Lebak District, the Head of Baduy Luar Village, the Secretary of Kanekes Baduy Luar Village, Sarpin (the education figure at Baduy Luar 
Village), andthe Centre of Society Learning Activity (PKBM) in Leuwidamar Sub-district of Lebak District.

The data collection techniquesemployed were documentation, observation, and in-depth interviews. Triangulation, particularly data triangulation, wasemployed to verify the validity of the data in which more thanone technique is used for checking the purposes or as a comparison between theobtained data. The analytical technique used is qualitative analysis. First, the categorization of issues related to the evaluation of education policy within Baduy society in Lebak District was obtained through observation, in-depth interviews from key informants, and documentation. Second, the data and information collected were then analyzed by triangulation technique to get an understanding of the interpretation of the problem under study. Third, the result of the triangulation was then used as the basis for the conclusion of the research results.

\section{FINDINGS AND DISCUSSION}

\section{A. Directly moreoriented to program activities than program objectives}

Baduy society is located in Kanekes Village, Leuwidamar Sub-District, Lebak District, Banten Province. Geographically, the location of the Baduy society is located at 627'-6o 30 'North Latitude (LU) and 108o 3'-106o 4'Last East (BT) within an area of about 5,101.85 hectares (Garna, 1993: 124-135; Iskandar, 1992:21; Iskandar \& Ellen, 2000:5; Permana, 2009:86; Permana, 2010:21-22). Until now, the Baduy people are still tied to the pikukuh (custom rules) passed down from generation to generation. One of the pikukuhis calledlojor teu meunang dipotong, pondok teu meunang disambungan, meaning that the length should not be cut, whilethe short should not be connected. In other words, it should not change something acceptablethat already exists throughneither adding nor subtracting it (Permana, 2009:92). Any person violatingthepikukuh will obtain customary punishment from the Puun (the highest tribe leader).

Achieving the objectives of a policy is said to be effective if the intended goal set forth in the policy document for a certain time is achieved and beneficial to society. Therefore, the regional regulation of Lebak District No.2/2010 about the implementation of education. The education policy mandated by the government for Baduy people needsparticular responses. It is because there is a rule that forbids Baduy people to go to school this matter in which it is considered as a taboo by the society who strongly rejects modernization. It is very unique and interesting to get special attention, so that the local regulation related to education can be run and implemented in accordance with what is expected.Then it can be developed by taking into account the supporting capacity of the environment and local human resources, so that the society can participate in various policies, especially education-related policies, and the government will be benefited in improving local human resources (HR) and in turn will improve the welfare of the society. This is because there is no operational guidance from the regulation in the form of Regent Regulation causing ineffectiveness of the policy in the framework of education policy withinBaduy society in Lebak District, so what is the purpose of the policy has not been fulfilled.
Referring to the analytical tool on the theory of formal evaluation,the objectives and targets formally announced are appropriate measures for the benefits and values of program policies. This approach results in two types of evaluation derivation: summative evaluation and formative evaluation. Summative evaluation includesthe efforts to monitor the achievement of formal objectives and targets after a policy or program is implemented for a certain period of time. This policy's evaluation criterion is in line with Samodra (in Wibawa, et al., 1994:64) that program effectiveness refers to the level of goal attainment, while efficiency essentially questions some comparison between the input and output of the program.

The education within Baduy societycannot be effectivefor the reason of Baduy people reject the schooling in their customs. The role of Education and Culture Office of Lebak District as the policy administrators cannot do more for the success of education policy for Baduy people. They find it extremely difficult to realizethe government programs related to formal education for Baduy people, so that they cannot only focus on a single target group in the success of this education policy.

One of the Baduy people's obligation is to preserve the nature. They learn and live with nature. Therefore, there will be no Baduy residents in formal school, except those who leave Kanekes Village and not return to it. School is one of the things that is prohibited in the life of Baduy Dalam (one of the names of Baduy society). One ofthe causes of the failure on the illiteracy eradication program is due to the existence of indegineous Baduy Dalam dan Baduy Luar who do not want to go to school. A more specific and operational regulation is needed, especially to be able to approach Baduy people without breaking the customary rules. Thus, it can be concluded that the objectives and benefits of the policy can be realized if it can be published as a reference for illiteracy eradication program in Lebak District, especially in Leuwidamar Sub-District for indigenous Baduy people.

\section{B. Responding to the informant requirement of the audience}

As proposed by Sihabudin (2009), in Lebak District, Leuwidamar Sub-District, there are Baduy people living in the area of Kanekes Village, Leuwidamar Sub-District called Baduy Dalam and those living outside the area called Baduy Luar. There are three villages in the area of Baduy Dalam, namely: Cikeusik, Cikertawarna, and Cibeo in which each is led by a custom leader or commonly called Pu'un. While, Baduy Luaris spread in 61 villages. Among others, they are: Kadu Ketug, Kadu Meng, Gajeboh, Kadu Kohak, Cipiit, and Kadu Jangkung.

The Baduy tribe is not an isolated tribe, but a tribe deliberately alienating itself from the outside life. The compliance of Baduy people in carrying out their ancestral mandate is very strong, strict, and firm, but still in a democratic nuance. Along with the historical journey, they are a group of people who in their daily life do not know the writing culture. Everything related to the rules of custom law, education, stories of their ancestors, and their beliefs is passed down and passed on to their offsprings orally. 
As stated by Wicaksana (2017:86), oral culture greatly influences the pattern and understanding of the Baduy tribe education. They have a unique pattern and understanding, namely the model of papagahan education (mutual teaching among the citizens). The learning is directed at providing an understanding of the foundations of custom law delivered orally and accompanied by direct practice for each of the citizens. They have absolutely no custom rules in written form, which may lead to the difficulties of an educational model that puts forward the writing culture, as in the model of Indonesian society.

It suggests that the prohibition of formal education among the indigenous people is actually not as sacred as we might expect. The author sees that in the traditional Baduy society, education is already run with a model or a special formula and certainly different from the concept of modern education that the Indonesian people employ. The concept of proper education, needed by the indigenous Baduy people, does not conflict with their custom law, while the gap regards exist. In other words, a growing number of schoolsprovide alternative education for Baduy people. It is reading, writing, and numeracy skills.

Regardingthe Baduy society and its culture, of course we cannot escape from the ethnographic view that has long been written about Baduy. Surely, we will refer to Jul Jacobs telling the Baduy in the 1890s, while Gaise in the 1950s, and Judistira K. Garna in the 1980s. From the three ethnographies,it tells the milestone of Baduy's life and culture in facingthe constant changes. The authors, agreed one another in their writings that were compiled at different times, expected to answer most people's enquiry questioning whether these Baduy people will be extinct or their extinction is near. According to the three ethnographies, Baduy is not going to be extinct and will still survive in the exposure of changes from time to time.Indigenous Baduy people respond to the changing circumstances countering their cultural life. They have a cultural mechanism that is actually used as a guide to deal withit. Teu wasa(one of the obliged principles) and pikukuh are taughtand always practiced in daily life (Garna, 2008:84).

The local Regulation of Lebak District No.2/2010suggests some efforts undertaken in advancing the education; among others are: making smart lebak card, providingassistance for poor student (BSM), creating a village library or society reading park (TBM), increasingthe PKBM, launching literacy movements from educational activists, enhancing early childhood education (PAUD), creating mobile libraries, providing accommodation, organizing entertainment and recreation activities to attract learning interests, holding intensive teaching meetings, and other government programs that encourage the success of illiteracy eradication program.

Baduy Dalam people have their own custom way of providing education to the children, but still support the education policy under their custom rule; that is reading and writing from the Baduy people. Guests or outsiders of the Baduy Dalam are forbidden to teach becausethey are afraid ofbeing disruptedupon their custom. However,Baduy Luarpeopleare very open for educators and teachers from immigrants. At Ciboleger Village, there has been a State
Elementary School in which the school has already got a lot of Baduy Luar people mingling with the surrounding people. In addition, there are: an official school, reading parks, and study groups.Even,some Baduy Luar people havetaken Package B and $\mathrm{C}$ for certificate equivalence, so they can continue to higher education.

\section{Valuing different perspectives of the people served are reported in the success and failure of the program}

Public policies evaluated in accordance with those described by James P. Lester in Lester and Joseph Stewart (2000) relate to an assessment of the consequences of a public policy. Essentially, there are two main goals of policy evaluation. First, it is to determine what the consequences of a policy are by describing its impact. Second, it is to assess the success or failure of a policy in accordance with predetermined standards and conditions.

Rusli, (2013:113-114) mentioned, "That the success or ability to disclose a problem must be followed by an effort to provide constructive input for an improvement." The popular term is constructive input rather than criticism without a solution which can be understood and acted upon by those criticized. Ideally it is so, though such things are rarely done and then accepted by those who are the subject of evaluation.

The followings are the custom rules that cross the formal education concept. Excerpted from the explanations of the indigenous figure of Baduy Dalam, Mursyid (Vice Jaro Tangtu, Cibeo, Baduy Dalam), there are three main rules. First, indigenous Baduy people get the mandate to live simple in order to remain faithful and togetherness. If they are given the freedom to seek knowledge and progress,it will surely be a competition of life, while knowledge and progress has no limit. Finally,they continue to race and forget Wiwitan and the real purpose of life.Second, the existence of formal education such as school will take the students'time because the fixed schedule has been determined. It is becausethey alsohave full of custom activities that must be carried out by every citizen without exception; that is farming and other activities. So, if the children attend formal school, certainly many customary activities are disturbed. Thirdly, the customary land should not be changed including the form of a house or a building.If a permanent school is built in ulayat land, it is certain to be in conflict with the basic custom law. Fourth, according to them learning to read, write and counting is not unnecessary and not important. Calistung (the acronym for the three skills) or other sciencesare regarded as complementaryto balance the life and associatedpeople.

If modern education is urged to be taught, then the impact is that they will no longer maintain their customs, and will automatically also impact on the destruction of nature. Perhaps, modern education can make the Baduy society more technologically advanced, but has a negative impact because it introduces them the sparkling outer world that is full of capitalist and indiviualism, which is certainly very contradictory with the advice of Baduy customs.

Natural environmental condition that exists in the area of indigenous Baduy people is a special attraction for visitors and becomes one of the cultural attractions in the Lebak District. 
Even, in spite of the rapidly changing times, the existence of indigenous customs and custom laws in Baduy society still stands, although there is a shift in value.Although there is a shift in value, it does not make a fundamental change in the pattern of life of their customs. So, the accuracy in this education policy needs to pay attention to the continuity of the pikukuh or customs they hold. The government and other societies have to learn much from the life of Baduy people, although there are a lot of changing currents trying to influence their culture and customs.However, with the conviction of their customs, to this day, Baduy people still try to preserve their cultures.So the government needs to support the people's customs, so that they cannot easilymandatea policy if it is not in accordance with the custom rules of Baduy people.

Presumably,considering the prohibition to read and write, they do not have the calculations of the year. Nevertheless, they know precisely on which month they are being inthat they create by looking at the position of the sun and the image of the stars in the sky. In this case, they know:

OrioncalledGidangor guru Desa (said 'village teacher')

Venus calledBintang Timur (said 'east star)

Piciadencalled Kartika (a proper name)

.....? calledPamahpalan Badak

In the position of these stars, they organize work in their fields and religious festivals. They divide one year in 12 months in which each month consists of 30 days.Meanwhile, the names of the month are: 1 . kasa; 2 . karo; 3. katiga; 4. sapar; 5. kalima; 6. kanem; 7. kapitu; 8. kadalapan; 9. kasalapan; 10. kasapuluh; 11. hapit lemah; and 12. hapit kayu. The names of the days are as follows: 1. Ahad (Ngahad); 2.Senen; 3.Salasa; 4.Rebo; 5.Kemis; 6.Jumaat; dan 7.Saptu. The seven days become one week (said 'sa-ahad').

In addition, indigenous Baduy people have their own way of counting by using simple measuring units. At a glance,regarding the sizemeasure of an area, as well as the size of the Baduy group is very uncertain. Most of the distance is determined by calling the number of ridges that must be passed with the words 'jongjongan rangkong' (number of rivers), 'sapawanupahan' (length of time to chew sirih), and so on (Garna, 2012:131-132).

It should also be pointed out that to indicate the location of objects such as two adjacent or adjacent bodies, they do not mention the right and left, but using the terms wind direction, kaler (for the north), kidul (for south), wetan (for the east), andkulon (for the west). Thus, they will not say "to the left door" but "to the south door". It is generally known by all the tribes in the archipelago and many more of these nations using this way.

Sectoral integration means that there is a need for coordination, tasks of authority and responsibility between sectors and government agencies; both central, provincial, district, sub-district, and village. The integration of the scientific point of view requires that the education policy should be implemented on the basis of interdisciplinary science or involving the field of science: ecology, sociology, geology, law, and other relevant disciplines according to the object/subject of development. Thus, this is what should be done because the area of indigenous Baduy people basically consists of complex and dynamic social and cultural systems supportedby human resources that are less competitive and left behind, but are responsible for the customs and culture they have maintained since hundreds of years ago.

\section{CONCLUSION}

Regarding the first criterion, "Directly moreoriented to program activities than program objectives"some points are obtained from the reflectionon the policy objectives: (1) the limited accessibility, while the policy has been implemented; (2) the development of human resources (SDM) should be taken into account by the local government as the society service provider in accordance with the law like providing the facilities and infrastructure, supporting infrastructure of education, and providing excellent service.

Considering the second criterion, "Responding to the informant requirement of the audience", it is the oral culture that greatly affects the pattern and understanding of education among Baduy tribe. They have a unique pattern of understanding, namely the model of papagahaneducation (mutual teaching between citizens). The learning is directed at providing an understanding of the foundations of custom law delivered orally and accompanied by direct practice from each of the citizens. Although the Baduy Dalam people do not receive formal education as inthe modern society, they can still fulfill their daily needs from the nature that they keep their sustainability.

The last yet not least criterion, "Valuing different perspectives of the people served are reported in the success and failure of the program", includesthe sectoral integration through coordination, tasks of authority, and responsibility between government agencies, whether central, provincial, district, sub-district, or even village. Meanwhile, the integration of the scientific point of view requires the application of education policy that is on the basis of interdisciplinary science or involving the field of science: ecology, sociology, geology, law, and other relevant disciplines according to the object/subject of development.

\section{RECOMMENDATION}

1) In accordance with the results of the research,it needs to be given academic attention regarding the local regulation number $2 / 2010$ on the implementation of education in Lebak District. It needs to be reviewed in accordance with the higher regulations above it and adjust the needs of community-based educationpolicyas well asthe local wisdom ofindigenous Baduy people.

2) The Education and Culture Office of Lebak District needs to improve the competence through education and training according to the field of duties and functions in supporting the implementation of education policy within Baduy society.

3) Providing authority to the Head of Education and Culture of Lebak District to managethe programs related to the accessibility and support of education policy in Baduy in an 
integrated and sustainable manner besides its duties and functions.

4) Local government through the Education and Culture Office of Lebak Districtshould give awards to officers, executors, non-formal education organizers, and volunteers of literacy activists who concentrate on the success of education policy within Baduy society of Lebak District.

5) The expected integration of programs between agencies isto support each other in the implementation of this policy or programs. It needs to be done integratedly based on the local wisdom paying attention to customs, looking at the environment and community empowerment.

\section{REFERENCES}

[1] Adimihardja, Kusnaka. 2000. Orang Baduy di Banten Selatan: Manusia Air Pemelihara Sungai, Jakarta. Jurnal Antropologi Indonesia, Th. XXIV, No. 61, Januari-April 2000, FISIP, Indonesia University.

[2] Anderson, James E.1979. Public Policy-Making. USA : Lay Holt, Rinchart and Winston.

[3] Bruce Mitchell, 1997. Resource And Environmental Management, "terjemahan Pengelolaan Sumberdaya Dan Lingkungan/, B. Setiawan, Dwita Hadi Rahmi in 2000”. Yogyakarta: Gajah Mada University

[4] Creswell, John W. 2010. Research Design.Qualtative \& Quantitative Approaches. Jakarta: Kik Press

[5] Dunn, William N. 2000, Pengantar Analisis Kebijakan Publik. Yogyakarta: Gajah Mada Universitas Press.

[6] Garna, Judistira K..2008. Budaya Sunda Melintasi Waktu Menantang Masa Depan. Bandung: Lembaga Penelitian Unpad and The Judistira Garna Foundation.

[7] Garna, Judistira K dan Hardjadilaga, Salam. 2012. Etnografi Jul Jacobs "Orang Baduy dari Banten". Bandung: Primako Akademika and Judistira Garna Foundation.

[8] Howlet, Micvhael and M. Ramesh. 1995. Studying Public Policy: Policy Cycles and Policy Subsystem, Oxford University Press.

[9] Iskandar, Johan., 1992. Ekologi Perladangan di Indonesia. Studi Kasus Dari Daerah Baduy Banten Selatan, Jawa Barat. Jakarta: Djambatan.

[10] Jones, Charles O. 1984. An Introduction to the Study of Public Policy. Massachusse: Duxbury Press.

[11] Kusdinar, Aan. 2004. Kebijakan Pemerintah Kabupaten Lebak dalam Penanganan Komunitas Adat Terpencil Baduy.Proceeding at
Pengembangan Kawasan Tertinggal Berbasis Komunitas Adat TerpencilSeminar. Jakarta: Direktorat Pengembangan Kawasan Khusus dan Tertinggal BAPPENAS.

[12] Lester, James P, Joseph, Stewart. 2000. Public Policy An Evolutionary Approach. Wadsworth, Stamford, USA.

[13] Nugroho, Riant. 2014. Public Policy : Teori, Manajemen, Dinamika, Analisis, Kovergensi, dan Kimia Kebijakan (edisi kelima, revisi). Jakarta : PT. Alex Media Komputindo.

[14] Parsons, Wayne. 2005. Public Policy Pengantar Teori dan Praktik Analisis Kebijakan. Jakarta: Kencana.

[15] Permana, Raden Cecep Eka., Isman Pratama Nasution, and Jajang Gunawijaya. 2011. "Kearifan Lokal Tentang Mitigasi Bencana Pada Masyarakat Baduy". Jurnal Makara, Sosial Humaniora, Vol 15, No 1 Juli 2011:67-76. Jakarta: Indonesia University

[16] Rusli, Budiman, 2013. Kebijakan Publik Membangun Pelayanan Publik yang Responsif. Bandung: Hakim Publishing.

[17] Sihabudin, Ahmad. 2009. Persepsi Komunitas Adat Baduy Luar Terhadap Kebutuhan Keluarga Di Kabupaten Lebak Provinsi Banten. Disertasi.Program Pascasarjana. Bogor: Bogor Agriculture Institute.

[18] Tangkilisan, Hassel Nogi S. 2003. Evaluasi Kebijakan Publik : Penjelasan, Analisis \& Transformasi Pikiran Nagel. Yogyakarta: Balairung \& Co.

[19] Weiss, C.H. 1998. Evaluation: Methods for Studying Programs and Policies. 2nd edition Upper Saddle River, NJ: Prentice Hall.

[20] Wibawa, Samodra. 1994. Kebijakan Publik: Proses dan Analisis. Jakarta: CV. Intermedia.

[21] Wicaksana, Harits Hijrah. 2017. Evaluasi Program Pengentasan Buta Aksara di Kabupaten Lebak Pada Masyarakat Adat Baduy Kabupaten Lebak Provinsi Banten. Dissertation. Postgraduate Program of FISIP. Bandung: Universitas Padjadjaran

[22] Winarno, Budi, 2002, Teori dan Proses Kebijakan Publik, Media Pressindo, Yogyakarta.

[23] Wirawan. 2011. Evaluasi: Teori, Model, Standar, Aplikasi, dan Profesi (Contoh Aplikasi Evaluasi Program: Pengembangan Sumber Daya Manusia, Program Nasional Pemberdayaan Masyarakat (PNPM) Mandiri Perdesaan, Kurikulum,Perpustakaan, dan Buku Teks). Jakarta: PT. Raja Grafindo Persada.

[24] Regulation of Lebak District government, No. 32/2001 about the protection of Baduy Society rights.

[25] Regulation of Lebak District government, No. 02/2010 about the implementation of education in Lebak District.

[26] Mandate of The Lebak Regent, No. 590/Art. 233 /Law/2002 about the arrangement of custom landmarks of Baduy society at Kanekes Village, Leuwidamar Sub-District, Lebak 